Universidad de Guadalajara

DERECHO GLOBAL. ESTUDIOS SOBRE DERECHO Y JUSTICIA

Año 2021, Vol. VI. Número 18, Julio-Octubre, ISSN: 2448-5128 e-ISSN: 2448-5136

https://DOI.org/10.32870/dgedj.v6i18.410

MARIA ANGUSTIAS MARTOS CLABRÚS

UNIVERSIDAd DE ALMERÍA, EsPaÑa

mamartos@ual.es

\title{
COMUNIDAD DE PROPIETARIOS Y VIVIENDAS DE USO TURÍSTICO
}

\section{COMMUNITY OF OWNERS AND HOLIDAY HOMES}

Cómo citar el artículo:

Martos M, (2021). Comunidad de Propietarios y Viviendas de uso Turístico. Derecho Global,

Estudios sobre Derecho y Justicia, VI (18) https:/DOI.org/10.32870/dgedj.v6i18.410 pp. 127-169

Recibido: 04/10/2020 Aceptado: 10/03/2021 


\title{
RESUMEN
}

Con la modificación del artículo 17.12 de LPH por Real Decreto-Ley 7/2019, de 1 de marzo, de Medidas urgentes en materia de vivienda y alquiler, las comunidades de vecinos pueden prohibir, mediante acuerdos de la Junta, que una vivienda del edificio pueda constituirse como vivienda de uso turístico. En el presente trabajo se analiza el régimen jurídico de dichos acuerdos y sus efectos. Dada la no retroactividad de la norma, se estudiará también la posibilidad de ejercicio, por la comunidad, de la acción de cesación del artículo 7.2 LPH, como vía para limitar el uso turístico de las viviendas.

\section{Palabras clave}

Comunidad de propietarios, viviendas de uso turístico, acuerdos de la junta de propietarios, limitación del uso turísticos de la vivienda, acción de cesación.

\begin{abstract}
With the modification of article 17.12 of LPH by Real DeCreto-Ley 7/2019, of March 1, on Urgent Measures in the area of housing and renting, the communities of neighbours can prohibit, by means of agreements of the Board, that a dwelling of the building can be constituted as a dwelling for tourist use. This paper analyses the legal regime of these agreements and their effects. Given the non-retroactivity of the norm, the possibility of the community exercising the injunction of article 7.2 LPH, as a way to limit the tourist use of the dwellings, will also be studied.
\end{abstract}

\section{KEYWORDS}

community of owners, holiday homes, agreements board of owners, to limit the holiday homes, cessation action.

Sumario: I. Problemática de la Vivienda de Uso Turístico. II. El alojamiento en Vivienda Turística Vacacional. III. La Vivienda Turística Vacacional y la Comunidad de Propietarios. IV. La limitación por la Comunidad de Propietarios del Uso Turístico de la Vivienda. 1. La limitación del Uso Turístico de la Vivienda en el Título Constitutivo o 
en los Estatutos. 2. La limitación del Uso Turístico de la Vivienda por acuerdo de la Junta de Propietarios. 3. La limitación del uso turístico por acuerdo de la Junta de propietarios antes de reforma de la LPH por el Real Decreto Ley No7 de 2019. 4. La limitación de la cesión temporal de la vivienda para uso turístico por acuerdo de la Junta de propietarios conforme al Real Decreto Ley No 21 de 2018 y al Real Decreto Ley No 7 de 2019. 5. El acuerdo de la Junta de propietarios para el incremento de la participación en los gastos de la comunidad a los propietarios de viviendas de uso turístico. V. La limitación del Uso Turístico de la Vivienda a través de la Acción de Cesación. 1. Presupuestos Sustantivos de la Acción de Cesación. a) El uso turístico de una vivienda como_actividad (económica) prohibida o ilícita. b) El uso turístico de una vivienda como actividad dañosa c) El uso turístico de una vivienda como actividad molesta [insalubre, nociva y peligrosa]. 2. Presupuestos Procesales de la Acción de Cesación. a) El requerimiento previo para el cese de la actividad. b) El acuerdo de la Junta para la interposición de la acción de cesación. c) Las medidas cautelares y pronunciamiento de la sentencia. VI. Conclusiones. Bibliografía.

\section{Problemática de la Vivienda de Uso Turístico}

El alquiler turístico de una vivienda, que constituía hace veinte años un caso aislado en el conjunto de un edificio, y que venía a conocerse por la presencia de un cartel en un balcón o en el portal, se ha potenciado en la actualidad por las facilidades que ofrece Internet. La Red permite hoy al simple particular propietario de vivienda acceder al mercado como si fuera un empresario y establecer una relación directa con el usuario, y sin costes de comercialización: es la llamada "economía colaborativa"1. Los nuevos alquileres vacacionales se han convertido en un fenómeno que preocupa a las Administraciones, al sector hotelero y a las comunidades de propietarios: un verdadero problema. A las primeras porque

\footnotetext{
${ }^{1}$ Como dice Fuentes-Lojo (2018) (www laleydigital.laleynext.es/7839/2018), la economía colaborativa está "permitiendo [así] a simples propietarios de viviendas el acceso a dicho mercado en condiciones de igualdad con grandes empresas hoteleras y centrales de reservas".
} 
supone una causa de degradación de barrios históricos ${ }^{2} \mathrm{y}$ de incremento del precio del alquiler de vivienda "para vivienda" y, de paso, del precio de las viviendas ${ }^{3}$, así como una bolsa de fraude fiscal ${ }^{4}$. Al segundo, porque la proliferación de las viviendas turísticas se ha convertido en un enemigo declarado de la actividad turística, digamos "reglada" (la Exposición de motivos de la Ley 41/2013 de medidas de flexibilización y fomento del mercado de alquiler de viviendas, habla de "intrusismo y competencia desleal"). Y, por último, a las comunidades de propietarios, por las molestias que causan los ocasionales vecinos de fines de semana o de semanas o quincenas de julio o agosto. Para atajar el problema, en sus diversas facetas, se modificó la Ley de Arrendamientos Urbanos (LAU) en el año $2013^{5}$ y se ha modificado la Ley de Propiedad Horizontal (LPH), recientemente, en 2018 y 2019 (por el inapropiado expediente del Decreto-Ley6); además de haberse desarrollado una específica legislación turística de rango autonómico (pues son las Comunidades Autónomas las competentes en materia turística, de conformidad con el art. 148.1.18 Constitución Española) y, en algún caso, hasta local ${ }^{7}$.

\footnotetext{
${ }^{2}$ Hay normas autonómicas que prohíbe el alquiler turístico en algunos barrios, como es el caso de la LEY $\mathrm{N}^{\circ}$ 8 de 2012, del Turismo de las Islas Baleares y de la LeY No 15 de 2018, de turismo, ocio y hospitalidad de la Comunidad Valenciana.

${ }^{3}$ Dice la Exposición de Motivos (apartado I, párrafo 6) del Real Decreto-Ley № 7 de 2019, de medidas urgentes en materia de vivienda y alquiler: "No cabe duda de que, aunque pueden existir diversos factores que explican este incremento de los precios, el fenómeno creciente del alquiler turístico de vivienda a través de plataformas p2p incide en un contexto en el que, además, la demanda de vivienda en alquiler está creciendo con intensidad".

${ }^{4}$ Como prevención de este presunto fraude la Agencia Tributaria dicto la ORDEN HFP/544/2018, de 24 de mayo, por la que se aprueba el modelo 179, "Declaración informativa trimestral de la cesión de uso de viviendas con fines turísticos" y se establecen las condiciones y el procedimiento para su presentación. A partir de enero de 2018 las plataformas tienen que realizar la declaración informativa donde tienen que hacer constar el nombre y la dirección de los anfitriones, detalles de sus anuncios y sus transacciones.

${ }^{5}$ Por la Ley No 41 de 2013, de medidas de flexibilización y fomento del mercado de alquiler de viviendas.

${ }^{6}$ Real Decreto-Ley N ${ }^{\circ} 21$ de 2018, que no fue convalidado por el Congreso en período de sesiones, y por el ReAl DeCReto-ley No 7 de 2019, de Medidas urgentes en materia de vivienda y alquiler, que fue convalidado por la Diputación Permanente del Congreso.

${ }^{7}$ Como es el caso de Plan Especial Urbanístico para la regulación de viviendas de uso turístico, aprobado por el Ayuntamiento de Barcelona con fecha 1 de abril de 2016, la legislación turística de la comunidad valenciana donde el uso de la vivienda como turística se ajusta a los planeamientos urbanísticos de cada localidad, quedando
}

\section{DERECHO GLOBAL. ESTUDIOS SOBRE DERECHO Y JUSTICIA}


De todos los problemas enunciados,-queremos dedicar las páginas que siguen al que afecta a las comunidades de propietarios, y que trata de resolver el Real Decreto-ley 7/2019, de 1 de marzo, de Medidas urgentes en materia de vivienda y alquiler, con la reforma del apartado número 12 del artículo 17 de la Ley de Propiedad Horizontal, al poner en manos de estas comunidades un instrumento de control, aunque, como veremos, no sea el único del que disponen.

Pero antes de tratar de esta cuestión, debemos abordar otra, aunque sea brevemente, porque de ella depende la aplicación o no de la nueva norma. Es una cuestión de definición (y de regulación), porque nos movemos entre el arrendamiento de temporada y la cesión de uso de vivienda vacacional y sólo éste está contemplado en el supuesto de hecho de la precitada norma.

\section{El alojamiento en Vivienda Turística VAcacional}

La vivienda vacacional, o "vivienda turística vacacional" o "vivienda de uso turístico" o "vivienda de vacaciones" (que, en Andalucía, se llama "vivienda con fin turístico") es una unidad habitable aislada (es decir, no integrada en un conjunto, porque daría lugar al apartamento turístico): un piso, apartamento, bungalow, villa, chalé o similar y, en general, cualquier vivienda situada en suelo de uso residencial que se ceda en régimen de alquiler, completa o por habitaciones, amueblada y equipada, y con inmediata disponibilidad, o sea, en condiciones de uso inmediato ${ }^{8}$.

\footnotetext{
al arbitrio de cada uno de los ayuntamientos las condiciones que deben reunirse (LeY $\mathrm{N}^{\circ} 15$ de 2018, de turismo, ocio y hospitalidad de la Comunidad Valenciana)y el Plan Especial para la regulación de los pisos turísticos del ayuntamiento de Madrid de 27 de marzo de 2019.

${ }^{8}$ En el contrato de alojamiento en vivienda turística vacacional la unidad de alojamiento no se caracteriza sólo por ser ésta aislada, sino por otros elementos que, dependiendo de la norma autonómica de que se trate, integran el objeto: determinado equipamiento de la vivienda (mobiliario general, mobiliario de cocina, ajuar, utensilios, etc., por ejemplo), suministros (agua fría y caliente, energía eléctrica, energía para la cocina, calefacción, por ejemplo), instalaciones y hasta algunos servicios (recogida de basuras, mantenimiento de piscina y jardín, por ejemplo), y todo con disponibilidad inmediata.
} 
El uso de esta vivienda se hace en virtud de un contrato de arrendamiento que, hasta el año 2013, era un arrendamiento de temporada regulado por la LAU. Este arrendamiento de temporada constituía una cesión temporal de uso de una vivienda, que estaba amueblada y lista para su uso inmediato. Sin embargo, con la reforma de la LAU llevada a cabo por la Ley $41 / 2013^{9}$, se introdujo en el artículo 5 una letra e) que excluía determinadas cesiones de uso del régimen de los arrendamientos de temporada. Para la exclusión hacía falta que la cesión temporal de uso fuese: (i) de la totalidad de una vivienda; (ii) que la vivienda estuviera amueblada y equipada en condiciones de uso inmediato; (iii) que fuera comercializada o promocionada en canales de oferta turística; (iv) que la cesión fuera lucrativa; y (v) que la cesión estuviera sometida a un régimen específico, derivado de su normativa sectorial (turística). Es obvio que los únicos elementos diferenciadores eran (iii) y (v), porque el arrendamiento de temporada (sea cual sea la temporada) era y es, por definición un contrato oneroso, y porque habitualmente era y es de una vivienda completa, amueblada y equipada en condiciones de uso inmediato. Otra cosa son las exigencias (iii) y (v).

Como decimos, la LAU viene excluyendo desde 2013, de su regulación, la cesión de uso de vivienda cuando ha sido "comercializada o promocionada en canales de oferta turística y [...] cuando esté sometida a un régimen específico, derivado de su normativa sectorial" (art. 5.e). Este texto ha sido modificado por el Real Decreto-ley 7/2019, que ha ampliado las vía de comercialización o promoción a "cualquier otro modo de comercialización o promoción"10. Actualmente, pues, resulta que: habrá contrato de vivienda de uso turístico (contrato de cesión de uso) cuando la oferta y la contratación de la vivienda se haya hecho a través de canales de oferta turística (redes p2p, páginas web, agencias de viaje, empresas mediadoras) o por cualquier otro modo de comercialización o promoción (prensa tradicional) y cuando en la Comunidad Autónoma en la que radique exista una norma que lo regule; y habrá contrato de arrendamiento de temporada,

\footnotetext{
${ }^{9}$ LEY N ${ }^{\circ} 41$ de 2013, de medidas de flexibilización y fomento del mercado de alquiler de viviendas.

${ }^{10} \mathrm{La}$ ampliación a "cualquier otro modo de comercialización o promoción" se hizo por el art. 1.2 del REAL Decreto-Ley No 21 de 2018, y, posteriormente, por el art. 1.2 del Real Decreto-Ley No 7de 2019.
}

\section{DERECHO GLOBAL. ESTUDIOS SOBRE DERECHO Y JUSTICIA}


regulado por la LAU, cuando en la Comunidad Autónoma no se haya regulado específicamente la cesión de vivienda vacacional o cuando al contrato no haya precedido comercialización o promoción, y la oferta se haya hecho privadamente. En la Comunidad Autónoma de Andalucía, la vivienda vacacional, que se regula actualmente por el Decreto 28/2016, de 2 de febrero, de viviendas con fines turísticos, establece, en su artículo 1.2.b, otra diferencia con el arrendamiento de temporada (regulado en la LAU), que, a su vez, constituye un límite a la contratación de este tipo de cesión de uso. Este decreto dice que el contrato de vivienda con fin turístico no puede superar los dos meses de duración y, además, excluye de su ámbito de aplicación las viviendas contratadas por tiempo superior a dos meses continuados por una misma persona, que se rigen por la $\mathrm{LAU}^{11}$. Ahora bien, ¿puede un decreto autonómico definir un tipo contractual, sea por la duración o por cualquier otro elemento? ¿Puede modificar el ámbito de aplicación de la LAU que la LAU establece? Claramente, no.

Pues bien, presupuesto que cualquier elemento diferenciador que no se encuentre en la letra e) del artículo 5 de la LAU no puede ser tenido en cuenta y que no existe diferenciación de tipos contractuales por el objeto contractual, la única diferencia entre un tipo de contrato y otro reside en la existencia o no de una norma especial y en el vehículo de la oferta contractual y de la contratación.

Por lo que hace a la existencia o no de norma autonómica sectorial, no hay cuestión. Hay norma o no hay, con independencia de que su alcance se haya extralimitado $^{12}$. Y si la hay, como es el caso de Andalucía, que ya sabemos que se extralimita en su norma, el primer elemento diferenciador y determinante del

\footnotetext{
${ }^{11}$ Pues bien, lo primero (i) es una limitación que puede establecer el Decreto autonómico, porque se refiere a un tipo de contrato regulado en el mismo Decreto y para el que tiene competencia el legislador autonómico. Distinto es el caso de lo segundo (ii), porque el legislador autonómico, menos aún el que solo tiene potestad reglamentaria, no puede limitar el alcance de una ley estatal como es la LAU (el citado Decreto viene a decir que sólo existe arrendamiento de temporada de la LAU cuando la cesión es por más de dos meses, cosa que no dice la LAU).

${ }^{12}$ Sobre la cuestión competencial vid. MesA (2019) (www.indret.com/pdf/1483.pdf).
} 
tipo se ha cumplido. Sin embargo, este elemento nos va a aportar alguna luz sobre el siguiente, que es menos claro. La norma reguladora a la que se refiere es "sectorial”, dice el artículo 5.e) de la LAU. ¿Qué es norma sectorial? Pues la norma que rige una rama o sector, y en el caso que nos ocupa ese sector es el turístico. Y sector turístico o Turismo es un tipo de actividad económica.

Por lo que hace al segundo, hay algo que decir. Aunque el artículo 5.e) de la LAU (y las especiales normas autonómicas) no lo digan, la verdadera línea de separación entre el arrendamiento de temporada y la cesión de vivienda de uso turístico no está (no puede estar) en la forma en que se haga la oferta contractual, sino en la actividad. Cuando el legislador introduce la letra e) en el artículo 5 de la LAU por medio de la Ley 41/2013, de 4 de junio, lo hace para evitar el "intrusismo y [la] competencia desleal" (Preámbulo II, in fine), se supone que con el sector hotelero y extrahotelero (reglado), porque no lo dice. En cualquier caso, lo que quiere evitar es el ejercicio de la actividad turística desde fuera del sector turístico. Con otras palabras, contratar a través de canales de oferta turística o por cualquier otro modo de comercialización o promoción es solo la evidencia de que existe una actividad turística, siendo ella la que produce la exclusión de la LAU. El alquiler en o durante una temporada turística no queda excluido necesariamente de la LAU, porque no siempre supone ejercicio de una actividad turística por parte del propietario, ni constituye siempre "intrusismo y competencia desleal". Lo que sucede es que el legislador de 2013 no dijo nada de la actividad, debiendo deducirse de lo que dijo, al introducir y luego modificar la letra e) del artículo 5 de la LAU, que contratar a través de canales de oferta turística o por cualquier otro modo de comercialización o promoción, aunque solo sea un contrato al año, supone actividad turística y, por tanto, actividad económica.

Presupuesta la existencia de regulación autonómica específica, es, por tanto, el hecho de que la cesión de uso suponga una actividad turística y económica, puesta de manifiesto por la oferta en operadores tales como Airbnb, Booking o 
Homeaway, o por agencias o por la prensa o por cualquier otro medio que no suponga una mera oferta privada, lo que es determinante para la cuestión que queremos analizar en estas páginas.

Evidentemente, las normas autonómicas establecen requisitos para poder desarrollar la actividad, pero estos presupuestos necesarios no caracterizan al contrato de cesión de vivienda turística. Por ejemplo, la actividad está sometida a declaración previa de la actividad ${ }^{13}$, pero la no declaración no convierte la cesión de uso de vivienda vacacional en un arrendamiento de temporada regulado por la LAU.

\section{La Vivienda Turística Vacacional y la Comunidad de Propietarios}

Algunas de las normativas autonómicas han prohibido el alojamiento en vivienda turística vacacional en edificios residenciales sometidos al régimen de propiedad horizontal ${ }^{14} ; \mathrm{y}$, en otras, se ha limitado ${ }^{15}$. En algunas de ellas lo que se hace es "recordar" que el título constitutivo o los estatutos de la comunidad

\footnotetext{
${ }^{13}$ Por ejemplo: en el caso de Andalucía, la persona que quiera ofrecer la vivienda deberá realizar una declaración "responsable" ante la Consejería competente, siendo inscrita de oficio la vivienda en el Registro de Turismo de Andalucía, con asignación de un código que habrá de indicarse en la publicidad que se haga de la misma y en la documentación; sin embargo, no es necesario que en el inmueble se exhiba una placa identificativa (art. 9 del DeCRETo No 28 de 2016). En el de Baleares, para llevar a cabo la "comercialización turística" de viviendas de uso residencial hace falta también formular con carácter previo una declaración responsable (art. 50.3 de la LEY $\mathrm{N}^{0} 8$ de 2012 de Turismo de las Islas Baleares).

${ }^{14}$ En Baleares, en el art. 52.3 de la Ley No 8 de 2012 del Turismo de las Islas Baleares, que decía hasta su reforma por LEY No 6 de 2017: "En ningún caso se considerarán aisladas las viviendas independientes que se encuentran en edificios plurifamiliares o adosados sometidos al régimen de propiedad horizontal, quedando en consecuencia prohibida la comercialización de estancias turísticas en este tipo de viviendas."

${ }^{15}$ En Baleares, en el art. 50.3 de la LeY N ${ }^{\circ} 8$ de 2012, del Turismo de las Islas Baleares, desde su reforma por LEY No 6 de 2017, a través de la declaración responsable de inicio de actividad de comercialización. En Galicia, el art. 5. 6. 2 del DeCRETo $N^{o} 12$ de 2017, de ordenación de apartamentos turísticos y viviendas turísticas, donde se contempla la eventualidad de acotar el número de máximo de viviendas de uso turístico por edificio por cada ayuntamiento.
} 
de propietarios, debidamente inscritos en el Registro de la Propiedad, pueden prohibir la comercialización turística de viviendas ${ }^{16}$. De hecho, es que, en los últimos años, muchas comunidades de propietarios se han planteado prohibir esta actividad por ser incompatible o contraria a la normal convivencia en un edificio residencial.

Sin embargo, el uso turístico de vivienda sita en un edificio en régimen de propiedad horizontal no está prohibido por ninguna norma de carácter general. Lo único que está prohibido es la actividad molesta, cuando la actividad de cesión de vivienda de uso turístico lo sea, de conformidad con el Decreto 2414/1961, de 30 de noviembre, por el que se aprueba el Reglamento de Actividades Molestas, Insalubres, Nocivas y Peligrosas.

En cambio, lo que sí ha hecho una norma general -el Real Decreto-ley 7/2019, de 1 de marzo, de Medidas urgentes en materia de vivienda y alquiler, que ha introducido en el artículo 17 de la Ley de Propiedad Horizontal (LPH) un apartado 12- es facilitar a las comunidades de propietarios que puedan, mediante acuerdos de la Junta, regular o prohibir los alquileres vacacionales en el edificio. Dice este artículo 17.12 LPH:

El acuerdo por el que se limite o condicione el ejercicio de la actividad a que se refiere la letra e) del artículo 5 de la Ley 29/1994, de 24 de noviembre, de Arrendamientos Urbanos, en los términos establecidos en la normativa sectorial turística, suponga o no modificación del título constitutivo o de los estatutos, requerirá el voto favorable de las tres quintas partes del total de los propietarios que, a su vez, representen las tres quintas partes de las cuotas de participación. Asimismo, esta misma mayoría se requerirá para el acuerdo por el que se establezcan cuotas especiales de gastos o un incremento en la participación de los gastos comunes de la vivienda donde se realice dicha actividad, siempre que estas modificaciones no supongan un incremento superior al $20 \%$. Estos acuerdos no tendrán efectos retroactivos.

\footnotetext{
${ }^{16}$ En Baleares, en el art. 50.7 de la Ley No 8 de 2012 del Turismo de las Islas Baleares, desde su reforma. En el Principado de Asturias, en el art. 27 letra B del DeCreto № 48 de 2016, de viviendas vacacionales y viviendas de uso turístico.
} 


\section{La limitación por la Comunidad de Propietarios del Uso Turístico de la Vivienda}

La prohibición o limitación de la actividad o uso turístico de una vivienda en algunas comunidades de propietarios se ha venido produciendo ante las reales o previsibles molestias que la existencia de viviendas turísticas pudieran generar para el conjunto de los residentes, como: la elevación del nivel de ruido, que perturba el descanso de los residentes, la menor limpieza de los espacios comunes, la pérdida de seguridad en el edificio y aparcamiento, así como el mayor desgaste y deterioro de las zonas comunes producido por el aumento de usuarios y la falta de cuidado, por tratarse de terceras personas ${ }^{17}$.

En principio el fundamento de esta limitación por la comunidad de propietario, según la doctrina jurisprudencial, es carácter perjudicial para la finca por el ejercicio de la actividad turística ${ }^{18}$. No obstante, también puede fundarse, como piensa González Pacanowsca, en un interés económico directo, pues, "tal restricción se traduzca en elevar precisamente el valor del piso (y el de los otros pisos de todos los vecinos) al asegurar (al menos en teoría) un ambiente más tranquilo, con la menor injerencia posible de personas totalmente extrañas a los propios comuneros" ${ }^{\prime \prime}$.

\footnotetext{
${ }^{17}$ Datos del Informe realizado por Exceltur en 2015, donde se entrevistaron federaciones y asociaciones vecinales de Barcelona, Madrid, Valencia, Granada, Toledo, Salamanca y Extremadura (www.exceltur.org/2015)

${ }^{18}$ La SAP de Barcelona (sección 13ª No392/2017 establece que "es plenamente legítimo y serio, y en modo alguno excesivo o anormal, el interés jurídico de la Comunidad de Propietarios demandada en que no se altere el destino de los departamentos del edificio, pasando de viviendas a viviendas de uso turístico, con la consiguiente introducción en el edificio de personas normalmente sin arraigo en el territorio, en una actividad normalmente de ocio, de uso temporal del edificio, sin responsabilidad frente a la Comunidad de Propietarios distinta de la extracontractual, normalmente sin la cobertura de un seguro, y en un uso incontrolado de los elementos comunes del edificio..., " y tampoco presuponga, necesariamente, que las mismas hubieren de ser dañosas, inmorales, peligrosas, incómodas o insalubres” como ya señalaba la STS No 134/1997.

${ }^{19}$ GONZÁLEZ (2003) p. 863. Más improbable resulta lo que dice ECHEVERRÍA (1997) p. 701, al apuntar a un interés, también económico, pero menos directo, consistente en restringir la competencia, al poseer otros negocios similares en las inmediaciones.
} 
Ahora bien, la limitación o prohibición de la actividad turística en el marco de una propiedad horizontal se puede producir por diferentes vías: originaria, por la prohibición expresa en el título de constitutivo o en los estatutos (inscritos, en su caso, en el Registro de la Propiedad), o derivada, por el acuerdo de la junta de propietarios. A su vez, el acuerdo de la Junta puede ser para modificar el título constitutivo y/o los estatutos o simplemente limitar o prohibir con un alcance temporal la actividad.

Por otra parte, según el tenor del art. 17.12, LPH la limitación de la actividad también puede hacerse por vía disuasoria, al permitirse establecer, para el propietario, una cuota especial o un incremento de la ordinaria.

\section{La limitación del Uso Turístico de la Vivienda en el Título Constitutivo o en los Estatutos}

El propietario único o el promotor del edificio, en la escritura de división horizontal o en los estatutos que se integren en ella, puede incluir alguna limitación de uso de los elementos privativos y, entre otros, la prohibición de cesión de uso de vivienda con fines turísticos ${ }^{20}$.

Para que esta limitación tenga efecto frente a los adquirentes, es necesario que la restricción de uso turístico de las viviendas aparezca de forma expresa en la escritura de constitución o en los estatutos, aunque también podría aparecer mediante una descripción de actividades prohibidas, como es el caso de la STS $\mathrm{N}^{\mathrm{o}} 7 / 2008$, donde se admite que en los estatutos pueda preverse la genérica prohibición de actividades que determinen una afluencia elevada de personas, la

\footnotetext{
${ }^{20}$ La STS No 1152/2008 determina que "el título constitutivo en el que se pueden establecer disposiciones en orden al uso o destino del edificio, sus diferentes pisos o locales', según el párrafo 3 del artículo 5.2 de la Ley de Propiedad Horizontal, e incluso imponer prohibiciones expresas respecto a concretas y específicas actividades no queridas por los copropietarios del edificio".
} 
cual podría resultar tanto de la actividad turística, como de la profesional o de la comercial $^{21}$.

Igualmente, es posible que en los estatutos no exista una prohibición expresa, pero sí una clausula donde se obligue a un acuerdo de la junta de propietarios autorizando la actividad, como reconoce la SAP de Barcelona, (sección 17 ${ }^{\mathrm{a}}$ ), $\mathrm{N}^{\mathrm{o}}$ $505 / 2008$ al considerar válida la cláusula estatutaria en la que se condiciona el destino o la realización de ciertas actividades en los pisos o locales a la previa autorización, por mayoría simple de la Junta de Propietarios ${ }^{22}$.

En cambio, la doctrina jurisprudencial no entiende que exista prohibición o límite de cesión de uso turístico de las viviendas cuando lo que se especifica en los estatutos de forma genérica es el destino exclusivo a uso de vivienda ${ }^{23}$ o cuando guarda silencio en la prohibición de ningún tipo de arrendamiento, como ocurrió en la SAP de las Islas Baleares Nº419/2009 que aunque quedó demostrado que el demandado cedía un uso turístico de su vivienda, al no contener en los estatutos una referencia expresa a modalidad arrendaticia alguna, la Comunidad careció de fundamento para paralizar esta actividad $^{24}$.

\footnotetext{
${ }^{21}$ Vid. también Sentencias del TS No 123/2006 y No 1023/2007.

${ }^{22}$ La LEY No 8 de 2012 del Turismo de las Islas Baleares, tras su modificación por Ley $\mathrm{N}^{\circ} 6$ de 2017, exige para poder comercializar viviendas turísticamente sometidas al régimen de propiedad horizontal, la no prohibición en el título constitutivo o estatutos y acuerdo de la junta de propietarios en el cual la mayoría de personas propietarias, que al mismo tiempo constituyen la mayoría de cuotas de propiedad, acepten expresamente la posibilidad de comercialización turística de las vivienda (Art. 50.7).

${ }^{23}$ La mera descripción de los elementos privativos como "pisos-vivienda", por tanto, no constriñe a sus titulares, restringiendo su aprovechamiento al de morada habitual, como ya aclaró la STS $N^{\circ} 123 / 2006$. Y señala que según la sentencia $\mathrm{N}^{\circ} 164 / 1996$, de la Audiencia Provincial de A Coruña (sección 1ª), en su fundamento jurídico segundo dice : "Tal como expresa la STS 23 noviembre 1995 , en supuesto similar al de autos, apareciendo en la escritura de declaración de obra nueva, que también es de constitución de régimen de propiedad horizontal, la descripción del edificio, compuesto de dos sótanos con destino a locales comerciales y plantas altas con destino a viviendas, tal especificación no puede suponer, respecto de estas plantas, sino el destino de sus partes, indivisas al uso de vivienda, sin que por lo tanto se puedan destinar para ningún uso comercial, ni a otra finalidad que no sea la de vivienda, con exclusión de cualquier otro destino".

${ }^{24}$ Sobre la limitación de las facultades dominicales y su interpretación restrictiva en los pisos y locales en régimen de propiedad horizontal. Vid. CABEZuelo (2018) pp. 19-51.
} 
Tampoco sería posible cuando por la falta de previsión por los estatutos se pretende considera un uso tertium genus, así la sentencia Juzgado de Primera Instancia de Granada No 130/2018, dice que "desde un primer momento la regulación estatutaria del edificio, artículo 2.1.3, incluso con la modificación efectuada (folios 20 y ss. de las actuaciones) resultaba suficientemente explícita respecto del destino de los departamentos, único de vivienda o de despachos o consultas profesionales, admitiendo, no obstante, el cambio de uno a otro, pero no que las viviendas se utilizaran para explotación como apartamentos turísticos alquilados por días, que significa un tertium genus que quedaba al margen de la autorización, a salvo la voluntad expresa de la Comunidad que implicaba la variación de los propios Estatutos. Sin que pueda considerarse como despacho, puesto que implicaba la morada de sus ocupantes, pero tampoco vivienda, al no suponer una permanencia temporal significativa ${ }^{25}$.

En todos estos casos, aunque exista normativa sectorial, turística, que regule la cesión temporal de vivienda con fines turísticos, aunque la vivienda cumpla los requisitos exigidos por esta, incluso, aunque tenga la licencia correspondiente, el propietario tiene que someterse al régimen estatuario de la comunidad, por lo que no podrá destinar su viviendas a tal actividad si está excluida en ese régimen. ${ }^{26}$ Por ello algunas normas sectoriales establecen como exigencia para otorgar la licencia de esta actividad, una certificación de la comunidad de propietarios de que no consta prohibida en los Estatutos, así como, en otros casos, un acuerdo de la Junta de propietario admitiendo la actividad, con el fin de evitar futuras controversias $^{27}$.

\footnotetext{
${ }^{25}$ En el mismo sentido la SAP de Valencia (sección $11^{\circ}$ ) N ${ }^{\circ}$ 512/2013.

${ }^{26}$ No faltan autores que piensan que estas limitaciones el derecho de propiedad de los copropietarios en los estatutos, son nulos de pleno derecho. Vid. MAGRo (2016) (www.elderecho.com/tribuna/civil/11_10185 55001. html).

${ }^{27}$ En Barcelona el artículo 7.1.e del Plan Especial Urbanístico para la regulación de viviendas de uso turístico, aprobado por el Ayuntamiento de Barcelona con fecha 1 de abril de 2016, el cual, al fijar los requisitos de la comunicación previa necesaria para que pueda iniciarse la actividad de uso turístico en viviendas, no sólo exige que se acredite por certificación de los estatutos que éstos no incluyen prohibición expresa del establecimiento de la actividad de vivienda de uso turístico, sino que va más allá y establece la exigencia de que, en caso
}

\section{DERECHO GLOBAL. ESTUDIOS SOBRE DERECHO Y JUSTICIA}




\section{La limitación del Uso Turístico de la Vivienda por acuerdo de la Junta de Propietarios}

Que la cesión de uso turístico de elementos privativos resulte prohibida desde el origen por título constitutivo, vemos que es posible, pero que la comunidad de propietarios pueda adoptar un acuerdo ${ }^{28}$ que limite los usos que pueden ser desarrollados en los elementos privativos, excluyendo el de vivienda de uso turístico, también lo es, aunque hasta finales de 2018 ha sido muy difícil por el requisito de la unanimidad que exigía de $\mathrm{LPH}$.

Con el fin de facilitar estos acuerdos se modificó la LPH por el Real Decreto-ley $7 / 2019$, de 1 de marzo, de medidas urgentes en materia de vivienda y alquiler, incluyendo un apartado 12 en su artículo 17, donde se establece la posibilidad de limitar o condicionar la actividad que se refiere la letra e) del artículo 5 de la LAU (vivienda de uso turístico) suponga o no modificación del título constitutivo o de los estatutos, requiriendo el voto favorable de las tres quintas partes del total de los propietarios que, a su vez, representen las tres quintas partes de las cuotas de participación.

\section{La limitación del uso turístico por acuerdo de la Junta de propietarios antes de reforma de la LPH por el Real Decreto Ley No7 de 2019}

\footnotetext{
de que los Estatutos no establezcan manifestación expresa relativa a tal actividad, deberá acompañarse a la documentación necesaria para que pueda entenderse autorizado el inicio de la actividad, un acuerdo de la Junta de Propietarios de aceptación expresa de la vivienda de uso turístico. En cambio, Andalucía, en el DeCreto N ${ }^{\circ}$ 28 de 2016, de las viviendas con fines turísticos, en contra del Dictamen 8/2014 de 22 de diciembre de 2014 del Consejo Social de Andalucía e incluso exigiéndose en el proyecto de ley, ha optado por el no sometimiento a los Estatutos.

${ }^{28}$ Para la validez de estos acuerdos, la doctrina jurisprudencial señala los siguientes requisitos: que deben constar en los estatutos de la comunidad; que la prohibición debe ser expresa, clara y concisa; que no contravengan la moral, las buenas costumbres ni el orden público; y que exista un interés legítimo ( STS No 358/2018 de 15 de junio). En el mismo sentido vid. Bethencourt (2019) p. 3049
} 
La junta de propietarios según la LPH, antes de la reforma por el Real Decreto Ley, podía tomar acuerdos que limitaran alguna actividad en las viviendas o en las zonas comunes según el artículo 17.6. Analicemos el régimen que tenían esos acuerdos y la eficacia de los mismos.

En cuanto al régimen de estos acuerdos, según $\mathrm{LPH}$, al constituir la prohibición de alquileres turísticos una limitación de propiedad dominical de los propietarios, no eran efectivos si no constaban en los estatutos, por lo que se requería que se modificasen los mismos. Por ello, era necesario que el acuerdo se adoptara por las mayorías exigidas para la modificación, es decir, la unanimidad de personas y de cuota de participación (art. 17.6) ${ }^{29}$. Así que, para prohibir la cesión de uso de vivienda con fines turísticos, cuando los estatutos o el título de constitución guardaban silencio, era necesario que todos los propietarios estuvieran de acuerdo, incluido el eventual propietario interesado en esta actividad, por lo que, en la práctica, limitar resultaba inviable ${ }^{30}$.

En Cataluña, en cambio, desde 2015 era posible, al igual que en LPH, conforme el Código Civil de Cataluña (CCCat)., que expresamente se incluyan en los estatutos las limitaciones de uso de los elementos privativos (art. 553.11.b), y que, cuando no conste se incluya mediante la modificación de los mismo por acuerdo, el cual era viable al exigirse las cuatro quintas partes de los propietarios que representen las cuatro quintas partes de las cuotas de participación (art. 553.26.2.a). Pero, antes de la reforma de la ley 5/2015, se exigía también (art.

\footnotetext{
${ }^{29}$ Cabezuelo (2018) pp. 19-51, opina que hay que distinguir entre una autorización ad hoc por mayoría de los copropietarios ante la solicitud de uno o varios vecinos, en ausencia de prohibición expresa en el título o mención alguna en los estatutos, y lo que representa en puridad una modificación del régimen estatutario y del título constitutivo, quedando reservada la unanimidad sólo a este último supuesto. Cuando se adopta en Junta de Propietarios un acuerdo sin vocación de permanencia donde no se alteran título ni estatutos, la modificación de esta voluntad convencional sólo exigiría mayoría simple de los propietarios. Basa su postura en sentencias sobre cambio de contribución de gatos (STS N 183/2013, SAP de Barcelona No 238/2011).

${ }^{30}$ En el preámbulo de la LEY n ${ }^{\circ} 6$ de 2017 relativa a la comercialización de estancias turísticas en viviendas que modifica LEY $N^{\circ} 8$ de 2012, de Turismo de Illes Balears, y con la finalidad de que los acuerdos sean efectivos, reconoce que solo será necesaria el acuerdo de la mayoría de los propietarios para la autorización.
} 
553.25.4) que los acuerdos que disminuyesen las facultades de uso y disfrute de cualquier propietario obtuvieran el "consentimiento expreso" de los propietarios afectados, dando lugar a diferentes resoluciones de la Dirección General de Derecho y Entidades Jurídicas de la Generalitat de Cataluña que negaron la inscripción de los acuerdos ${ }^{31}$. Estas resoluciones entendieron que la limitación estatutaria que prohíbe el destino de las viviendas a usos turísticos provocaba una disminución de las facultades de uso y disfrute del propietario afectado, lo que hacía necesario su consentimiento expreso para la validez del acuerdo. Así pues, como afirma Loscertales, en aquellos casos, en que la limitación se imponía sobre la totalidad de los elementos integrados en el régimen de propiedad horizontal, la disminución de las facultades de uso y disfrute afectaría a todos los propietarios, lo que, de hecho, suponía sujetar el acuerdo no sólo a una regla de unanimidad, sino de unanimidad expresa ${ }^{32}$. En cambio, con la nueva redacción del art. 553-25.4, solo precisa el voto expreso de un propietario para los acuerdos que supongan privación de cualquiera de las facultades de uso y disfrute de los elementos comunes y por tanto, que no puede aplicarse, en modo alguno, a la limitación del uso de las entidades como piso turístico.

Por lo que respecta a los efectos temporales de estos acuerdos, el Código Civil Catalán establece su no retroactividad, y por tanto, que no afectara a los propietarios que anteriormente hayan cedido el uso a través de alguna plataforma o agencia ${ }^{33}$. Sin embargo, en el caso de la LPH, guardaba silencio al respecto, y en cuanto necesitaba unanimidad de personas y cuota de participación, desde el acuerdo no se podría ceder este uso, y si se hubieran cedido con anterioridad a los acuerdos, tampoco podrá hacerlo desde el mismo.

En cuanto a los efectos de estos acuerdos, para los nuevos adquirentes de las vivienda, era necesario que constaran la modificación de los estatutos en el

\footnotetext{
${ }^{31}$ Resoluciones de la DGDEJ de 21 de abril de 2010 y 14 de septiembre de 2014.

32 Vid. LosCertales (2016) (www.sepin.es/2016SP/DOCT/20408)y en el mismo sentido Cremades J. (2012) (www.sepin.es/2012SP/DOCT/16915) y MARTí J. (2016) (www sepin.es/ SP/DOCT/20166).

${ }^{33}$ Vid. LOSCERTALEs (2016) (www.sepin.es/2016SP/DOCT/20408).
} 
Registro de la Propiedad, para que les fuera aplicables, ya que, sin ella, la norma estatutaria aprobada no afecta a terceros de buena fe, debiendo entenderse por tales los que todavía no habían adquirido en el momento de adoptarse el acuerdo $\mathrm{y}$, sin conocerlo, adquieren después y proceden a la inscripción de su derecho en el Registro de la Propiedad, con anterioridad al momento de inscripción del acuerdo (arts. 8, 32,34 y 38 de la Ley Hipotecaria) ${ }^{34}$.

Por último, cabía plantarse si eran válidos ${ }^{35}$ los acuerdos por los que la junta de propietarios pretendía suprimir una prohibición de uso turístico de las viviendas, o cambiar el uso de los elementos privativos que consta expresamente en los estatutos o en el título constitutivo. La respuesta tenía que ser afirmativa, siempre y cuando se adoptaran con las mayorías exigible por la LPH con anterioridad a la modificación, es decir por unanimidad, aunque como hemos indicado, poco probable, en cambio, sí serán más factible en el caso del CCCat. al exigirse la cuarta quintas partes.

4. La limitación de la cesión temporal de la vivienda para uso turístico por acuerdo de la Junta de propietarios conforme al Real Decreto Ley No 21 de 2018 y al Real Decreto Ley No 7 de 2019

Ante la imposibilidad de facto de prohibir la cesión de vivienda para uso turístico por las comunidades, el legislador, siguiendo a la normativa catalana, ha propiciado estos acuerdos, en un primer intento con el Real Decreto-ley No 21 de 2018, de 14 de diciembre y definitivamente con el Real Decreto-ley $\mathrm{N}^{0} 7$ de 2019, de 1 de marzo , de medidas urgentes en materia de vivienda y alquiler, donde se modifica la normativa de LPH introduciendo un apartado12 en el artículo 17, exigiendo solo el voto favorable de las tres quintas partes del total de los propietarios que, a su vez, representen las tres quintas partes de las cuotas de participación.

\footnotetext{
${ }^{34}$ Vid. ARNÁIz (2017) pp. 162-167 y MERINO (2016) vol. 6, pp. 537-554. También hay que tener en cuenta la SAP de Barcelona (sección 1a) No 708/2017 en el fundamento tercero cuando dice que "Cuestión distinta es que el cambio de destino sea oponible con efectos retroactivos a terceros que adquirieron los pisos o locales sin que constase inscrita la limitación en el Registro de la propiedad al impedirlo el art. 553-11, 3 del CCCat".

${ }^{35}$ En sentido contrario vid. MAGro (2016) (www.elderecho.com/tribuna/civil/11_10185 55001.html).
}

\section{DERECHO GLOBAL. ESTUDIOS SOBRE DERECHO Y JUSTICIA}


Vamos a analizar el régimen jurídico de estos acuerdos, tanto de los que se hayan podido adoptar ${ }^{36}$ durante la vigencia del primer Decreto y los que se hayan adoptados desde la entrada en vigor del Decreto-ley $\mathrm{N}^{\mathrm{o}} 7$ de 2019, de 1 de marzo, así como los efectos derivados de los mismos.

Según la nueva redacción del apartado 12 del artículo 17 de LPH, podrán las juntas de propietarios adoptar acuerdos, para que se "limite o condicione el ejercicio de la actividad a que se refiere la letra e) del artículo 5 de la LAU, en los términos establecidos en la normativa sectorial turística,", es decir, limitar que se puedan realizar actividad turística en las viviendas de propietario particular de un edificio en régimen de propiedad horizontal, cuando se oferte a través de plataforma colaborativas y conforme la normativa turística. Por tanto, se debe entender que cuando no nos encontremos estos supuestos no se podrá acordar la limitación.

El acuerdo debe de tomarse con la mayoría necesaria "tres quintas partes del total de los propietarios que, a su vez, representen las tres quintas partes de las cuotas de participación", es decir la norma viene a facilitar que las comunidades de propietarios puedan tomar los acuerdos sobre la admisión o prohibición de uso turístico de la vivienda de la propiedad que, como hemos indicado, eran muy difíciles por la exigencia de la unanimidad, siendo más generosa que la norma catalana.

Como hemos visto, para que la limitación por la Junta de cesión de uso turístico de una vivienda de un propietario, al tratarse de una limitación de propiedad dominical de los mismos tiene que constar en los Estatutos, es decir que será necesario la modificación de los mismos, tanto cuando guarde silencio, como cuando lo prohíba, para permitirlo, y para ello, con la reforma, solo será necesario las tres quintas partes del total de los propietarios que, a su vez, representen las tres quintas partes de las cuotas de participación.

\footnotetext{
${ }^{36}$ Este Decreto no fue convalidado por las cortes, por lo que esta normativa ha sido derogada, pero no podemos olvidar que durante el tiempo de vigencia (19 de diciembre a 24 de enero) se han podido adoptar acuerdos de esta naturaleza por las comunidades.
} 
En cuanto a los efectos de estos acuerdos, para los nuevos adquirentes de las viviendas, será necesario que conste la modificación de los estatutos en el Registro de la propiedad, para que les sean aplicables, como ya nos hemos referido al trátarlo antes de la reforma (arts. 8, 32,34 y 38 de la Ley Hipotecaria) ${ }^{37}$.

Por lo que respecta a los efectos temporales de estos acuerdos, el nuevo artículo 17.12 establece expresamente su no retroactividad, y por tanto, no afectará a los propietarios que anteriormente hayan cedido el uso turístico de sus viviendas y sólo a los que la pretendan realizar desde la toma del acuerdo. Esta consecuencia de aplicar el principio de no retroactividad da lugar a un trato inequitativo de estos propietarios con el resto ${ }^{38}$. Por ello, y teniendo en cuenta que estas estancias apenas duran más de unos días, y la mayoría en época vacacional, si el propietario deja de ofertar por un tiempo la vivienda, cuando quiera volver a ofertarla le afectará el acuerdo.

En cambio, ante este principio de no retroactividad, los que tenían esa actividad y la mantienen no se le puede prohibir por el acuerdo y solo quedaría la posibilidad de prohibirla por la acción de cesación cuando contravenga las disposiciones generales sobre actividades insalubres, nocivas, peligrosas o ilícita.

\section{Elacuerdo de la Junta de propietarios para el incremento dela participación en los gastos de la comunidad a los propietarios de viviendas de uso turístico}

La modificación por los RD de la LPH incluye la posibilidad, en los casos que se admitan por la comunidad la existencia de vivienda con usos turísticos, que a estos propietarios se les incremente su participación en los gastos de la comunidad.

Para que quede claro esta disposición es necesario definir la naturaleza de los gastos que dan lugar al incremento, así como la determinación de ese incremento y la existencia de los límites.

\footnotetext{
${ }^{37}$ Vid. nota 34.

${ }^{38}$ Con respecto al abanico de posibilidades absurdas que puede dar lugar la aplicación del principio de retroactividad en este supuesto vid. CARRASco (2019) (www.aranzadidigital.es/BIB 2019\595).
}

\section{DERECHO GLOBAL. ESTUDIOS SOBRE DERECHO Y JUSTICIA}


La obligación de contribuir a los gastos viene recogida en el artículo 9.1.e) de la LPH, realizándose "con arreglo a la cuota de participación fijada en el título o a lo especialmente establecido, a los gastos generales para el adecuado sostenimiento del inmueble, sus servicios, cargas y responsabilidades que no sean susceptibles de individualización".

Es decir que hay que distinguir los gastos generales, que dan lugar a la obligación de contribuir a los mismos según la cuota de participación, de los gastos particulares, que se satisfarán de acuerdo con lo previsto en los estatutos de la comunidad, o, en su defecto, según lo pactado.

El nuevo apartado 12 del artículo 17 de LPH permite que se adopte "un acuerdo por el que se establezcan cuotas especiales de gastos o un incremento en la participación de los gastos comunes de la vivienda donde se realice dicha actividad"; el legislador deja a la comunidad la facultad de calificarlos como gastos comunes o especiales.

Según el art. 9.2 de la LPH se consideran gastos generales "aquéllos que no sean imputables a uno o varios pisos o locales del edificio"; es decir, imputables a todas las viviendas y locales que conformen una propiedad horizontal. Serían pues, los gastos relacionados con los elementos comunes enumerados en el artículo 396 del Código Civil ${ }^{39}$. El criterio de reparto de los gastos que la Ley establece por defecto es la cuota de participación, siendo ésta el porcentaje del total del edificio que corresponde a cada piso o local. Para fijar la cuota de participación se toma como base la superficie útil del piso o local en relación al total del inmueble, su situación y emplazamiento, así como el uso que se presume que va a tener

\footnotetext{
${ }^{39}$ ESTRADA (1997) p. 694, considera que entre los gastos generales están los de conservación, reparación y necesarios del inmueble y sus servicios, que beneficia al edificio y/o a todos los propietarios, por lo que se reputan como gastos generales los de portería, administración, seguros, requerimientos y los que tienen que contribuir todas las fincas del edificio como consecuencia de su conservación, gastos estos que en definitiva son calculados y producidos antes de que se puedan producir la avería o rotura de un elemento común por su naturaleza, como sería el caso de la cubierta, estructura, tuberías, acometidas de agua y electricidad, los de ascensor, limpieza, jardinería, material de oficina, etc.
} 
de los elementos comunes. Y los gastos individualizados, son aquellos que se consideran una excepción a la regla general; serán los que no son imputables a todos los pisos o locales del edificio. Por ello se acepta que puedan tener esta consideración cuando se exonera al propietario de un determinado piso o local a abonar concretos gastos (ascensor, escalera) siendo necesario que conste en el título constitutivo o, en su caso, en los Estatutos comunitarios, o mediante acuerdo adoptados por unanimidad de la comunidad ${ }^{40}$. También se entiende de este tipo los gastos procesales derivados de pleitos entre la comunidad de propietarios y los comuneros ${ }^{41}$.

En el caso de las viviendas de uso turístico, que como las demás viviendas deben de pagar los gastos generales según su cuota de participación en la Propiedad horizontal, se le podrá repercutir también como establece el apartado 12 del artículo 17 , si se acuerda por la junta de propietarios, un incremento en esa cuota por realizar esta actividad, es decir, por el uso acentuado de los elementos comunes ya que claramente no debe repercutir al resto de los copropietarios ${ }^{42}$. La configuración como incremento en la participación en los gastos comunes, es posible ya que la jurisprudencia acepta que en los estatutos se pacten otros criterios de contribución distintos a los que resultarían del art. $5 \mathrm{LPH}$ que articule módulos diferentes a la cuota de participación fijada en el título constitutivo para cada piso o local ${ }^{43}$. Por tanto como la distribución de estos gastos viene determinada por la cuota de participación fijada en el título constitutivo y a lo especialmente establecido por la comunidad con referente a todas las unidades del edificio se tendría que acordar un sistema de distribución donde se tenga en cuenta el criterio de destino de la vivienda

\footnotetext{
${ }^{40} \mathrm{Vid}$. STS $\mathrm{N}^{\mathrm{o}} 335 / 2009$ y STS No 678/2016 donde en los estatutos declaran unos locales (sin acceso al portal ni escalera del inmueble) exentos de gastos de escalera y ascensor.

${ }^{41}$ Vid. la doctrina de las STS No 894/2011 y más reciente STS No 442/2018.

${ }^{42}$ Igual opina CABEZUELO (2018) p. 30, cuando indica que el sobrecoste que lleva aparejada la comercialización turística de un piso no ha de gravar, evidentemente, al resto de los copropietarios, que quedarían incólumes si aquel que se lucra se ofrece a cubrirlo. Es mayor el desgaste de unas instalaciones que pertenecen a todos y se requerirán frecuentes puestas al día o retoques.

${ }^{43}$ Así se pronuncian la STS 22 No 452/2008 y STS No 997/2005. En el mismo sentido vid. CERDEIRA (2018) p. 79.
} 
a uso turístico ${ }^{44}$. Ello levaría a que los propietarios de usos turísticos tendrían una cuota superior.

Si la comunidad decide configurarlo como gastos especiales o individualizados, se tratará de una cuota especial que sólo recaerá en las viviendas que tengan un uso turístico en cada momento.

Es conveniente que, en los acuerdos, sea del tipo que sea, se establezca el criterio a seguir, ante las circunstancias que se adquiera la vivienda por un nuevo propietario y no la quiera dedicar a uso turístico, para que en estos casos no le repercuta el incremento en los gastos, ya que si no se tendría que acordar la extinción del incremento mediante la junta y con la misma mayoría.

En lo que respecta al montante del incremento, el legislador no ha dejado libertad para que cada comunidad lo decida establecido, sino que ha establecido un límite, el $20 \%$ de incremento en la participación de los gastos, para evitar, seguramente, posible abusos de derecho ${ }^{45}$ por los vecinos.

En cuanto a las mayorías necesarias para acordar estos incrementos en el pago, ya no es necesario la unanimidad ${ }^{46}$ como para cualquier acuerdo de este tipo, sino "tres quintas partes del total de los propietarios que, a su vez, representen las tres quintas partes de las cuotas de participación".

Estos acuerdos darán lugar una modificación del Título o Estatutos y es aconsejable que se inscriban en el Registro de la Propiedad.

\footnotetext{
${ }^{44}$ No hay que confundir el reparto en los gastos con la de participación en el inmueble como pone de manifiesto la SAP Barcelona $\mathrm{N}^{\circ} 238 / 2011$.

${ }^{45}$ Vid. Cerdeira (2018) p. 80.

${ }^{46}$ Antes de la reforma se requería el acuerdo unánime de los propietarios para modificar la cuota de participación en los gastos comunes establecida en el título constitutivo (STS No 86/2012 con cita de la STS de 30 de abril de 2010).
} 
Por último, en cuanto a la eficacia de estos los acuerdos, según el apartado 12 del artículo 17, no son retroactivos, es decir tiene efectos ex nunc. Por tanto, el incremento de cuota se podrá aplicar a todos los pisos de uso turístico desde el acuerdo, a diferencia de lo que ocurría con los acuerdos de prohibición de las viviendas de uso turístico, pero no se podrán exigir el incremento de la cuota desde que se está dedicando la vivienda a uso turístico. En cuanto a los efectos a terceros, se le aplicaría a todo adquirente desde el momento que se dedique la vivienda a uso turístico si el acuerdo consta en los Estatutos.

Por último, como señala Sánchez González ${ }^{47}$, el pago de una cuota especial por los dueños de los pisos de uso turísticos, no merma la capacidad de la comunidad para interponer la acción de cesación por actividades "contrarias a la convivencia normal en la comunidad o que hicieran peligrar el inmueble", y como indica Cabezuelo Arena, por el impacto que la explotación turística tiene en otros derechos personales y patrimoniales de los propietarios en la misma edificación ${ }^{48}$.

\section{La limitación del USo Turístico de la Vivienda a TravéS de la ACCión de CESACIÓN}

El art. 7.2 de la LPH regula la acción de cesación o prohibición de una actividad por parte de la comunidad de vecinos cuando estén "prohibidas en los estatutos, que resulten dañosas para la finca o que contravenga disposiciones generales sobre actividades insalubres, nocivas, peligrosas o ilícitas”.

Ahora bien, no podemos afirmar, per se, que el uso de una vivienda para destino turístico contravenga las disposiciones generales sobre actividades que resulten molestas, insalubres, nocivas, peligrosas, ilícitas, lo que es lo mismo que sean

\footnotetext{
${ }^{47}$ SÁNCHEZ (2016) p. 102.

${ }^{48}$ La conflictividad que genera el destino turístico de un piso va más allá de un mayor desgaste de las instalaciones comunes, que es lo único que se cubre con ese aporte adicional. (Vid CABEZUELO (2018) y la STSJ de Cataluña No 37/2016.
} 
Comunidad de propietarios y viviendas de uso turístico

contrarias a la convivencia normal de la comunidad o la integridad del edificio, y mucho menos cuando se encuentran reguladas por la legislación sectorial ${ }^{49}$.

Sin embargo, está siendo muy frecuente que en determinadas zonas y ciudades, especialmente en temporada vacacional, los usuarios de estas viviendas lleven a cabo actividades ruidosa, se congreguen en un mismo apartamento para realizar actividades de ocio (beber, bailar, etc.), y otras conductas incívicas y antisociales ${ }^{50}$, dando lugar a que los propietarios del inmueble, se le generen grandes molestias personales y materiales ${ }^{51}$.

En estos casos en que la conducta de los usuarios de las viviendas de uso turístico sean contrarias a la convivencia normal de la comunidad o a la integridad de los elementos comunes del edificio, tanto si no consta como actividad prohibida, como si existe acuerdo de la junta de propietario admitiendo esta actividad, a los vecinos solo les queda denunciar la situación ante la propia junta y ésta en su caso proceder a interponer la acción de cesación a tenor del art. 7.2 de la Ley de Propiedad Horizontal. Y es que, como pone de manifiesto la STS No 123/2006, la acción de cesación tiene como fundamento reinstaurar la convivencia armónica en aquélla, cuya alteración puede haberse producido traspasando los umbrales de lo normalmente tolerable incluso en el ejercicio de una actividad reglada.

\footnotetext{
${ }^{49}$ Vid. VILA (2017) p. 36-39.

${ }^{50}$ Por la jurisprudencia se consideran conductas antisociales e incívicas, cuando arrojan los ocupantes de las vivienda de uso turístico en los espacios comunes las colillas, preservativos, etc. (STSJ de Cataluña $N^{\circ} 37 / 2016$ ) e igualmente como incívicas continuadas y graves, el mal uso continuo del ascensor, reiterados ruidos y fiestas nocturnos, actos de vandalismo, suciedad en los rellanos con restos de comida, botellas y robos (STSJ de Cataluña $\mathrm{N}^{\circ}$ 28/2014, con cita de la STSJC 17/2012).

${ }^{51}$ El informe Exceltur (2015) ha determinado que las mayores incomodidades para los vecinos del inmueble en propiedad horizontal generadas por una vivienda turística son: unos niveles de ruido que ( $82 \%$ ) perturban el descanso de los residentes; una mayor necesidad de limpieza ( 67\% ), por la mayor presión de uso sobre los espacios comunes; los inconvenientes $(42 \%)$ derivados de la pérdida de seguridad por la reiterada puesta a disposición de las llaves de la puerta de entrada de cada finca y de su parking a terceras personas desconocidas; los problemas de mantenimiento derivados de la mayor rotación que las cortas estancias introducen sobre el uso de las zonas comunes, con un mayor desgaste de las mismas, un 75\%. (http://www.exceltur.org/monograficos $8 /$ ).
} 
Vamos a analizar cuándo se puede interponer la acción de cesación del artículo 7.2 por considerar que el uso turístico de una vivienda contravenga las disposiciones generales sobre actividades que resulten moletas, insalubres, nocivas, peligrosas, ilícitas, observando que la existencia de la actividad tiene que ser de forma frecuente y que tiene que constituir situaciones anómalas o antisociales que ocasionen molestias objetivamente constatables ${ }^{52}$ o conlleven un uso excesivo y anómalo de las instalaciones comunes contraria a la normal convivencia en la comunidad ${ }^{53}$.

\section{Presupuestos Sustantivos de la Acción de Cesación}

Para que la comunidad de propietario pueda ejercitar la acción de cesación, es necesario que, como indica el precepto $7.2 \mathrm{de} \mathrm{LPH}$, el propietario u ocupante del piso o local realice, dentro del mismo o en resto del inmueble, una actividad prohibida por los estatutos, que resulte dañosa o contravengan la normativa sobre actividades moleta, insalubre, nociva, peligrosa, ilícita.

a) El uso turístico de una vivienda como_actividad (económica) prohibida o ilícita

Que se pueda prohibir en los estatutos el uso turístico de las viviendas de un edificio es posible como hemos podido ver. Por tanto, ante el incumplimiento de la prohibición la comunidad podrá exigir la detención de la actividad e interponer la acción de cesación. Igualmente se podrá solicitar cuando, estando permitida por los Estatutos, las normas sectoriales lo prohíban expresamente.

La acción de cesación en estos casos podrá solicitarse sin necesidad que se haya producido daño o molestias en la comunidad.

\footnotetext{
${ }^{52}$ Vid. MAGro (2016) http://www.elderecho.com/tribuna/civil/11_10185 55001.html.

${ }^{53}$ Vid. la STSJ de Cataluña № 37/2016, donde resolvió un recurso de casación sobre si el uso de pisos turísticos era contrario a la convivencia normal en una comunidad de vecinos. También la doctrina del TS que analiza GUILLÉN (2015) pp. 132-133.
} 


\section{b) El uso turístico de una vivienda como actividad dañosa}

En los casos en el que uso turístico de una vivienda esté permitida por los Estatutos y por la legislación sectorial aplicable, contando la vivienda con todos los permisos administrativos necesarios, puede que este uso resulte perjudicial para la comunidad a causa del menoscabo, o deterioro sufrido en la finca. En estos casos también puede solicitarse la acción de cesación como consecuencia de la obligación del propietario de realizar un buen uso de los elementos comunes y sus privativos del artículo 9.1 a) y b) LPH. ${ }^{54}$

En este sentido se pronuncia la SAP de Barcelona (sección 1 1a) No 34/2017 que rechaza aplicar la doctrina de los actos propios cuando se ejercita una acción de cesación si está admitida por los Estatutos, cuando la ejecución de una actividad consentida ha rebasado todos los límites imaginables, añadiendo que "una cosa es que la Comunidad demandante aceptase, como no podía ser de otro modo, el ejercicio de una actividad autorizada por la Administración y no prohibida en los estatutos y otra muy diferente que el ejercicio de la actividad se realice correctamente y de forma compatible con la vida en la Comunidad".

c) El uso turístico de una vivienda como actividad molesta [insalubre, nociva y peligrosa]

El artículo 3 del Reglamento de actividades molestas, insalubres, nocivas y peligrosas (Decreto 2414/1961 de 30 de noviembre), establece que:

"Son "molestas" las actividades que constituyan una incomodidad por los ruidos o vibraciones que produzcan o por los humos, gases, olores, nieblas, polvos en suspensión o sustancias que eliminen. Se calificarán como "insalubres" las que den lugar a desprendimiento o evacuación de productos que puedan resultar directa o indirectamente perjudiciales para la salud humana. Se aplicará la calificación de "nocivas" a las que, por las mismas causas, puedan ocasionar daños a la riqueza agrícola, forestal, pecuaria o piscícola.

\footnotetext{
${ }^{54}$ Vid. SAN Cristóbal (2009) pp. 61-84.
} 
Y por último, se consideran "peligrosas" las que tengan por objeto fabricar, manipular, expender o almacenar productos susceptibles de originar riesgos graves por explosiones, combustiones, radiaciones u otros de análoga importancia para las personas o los bienes".

Ante esta cuádruple descripción, Goñi Rodríguez ${ }^{55}$ entiende que el uso turístico de una vivienda en propiedad horizontal podría encajar en actividades molestas, o incluso dañosas cuando produzca un deterioro material de la zonas comunes desde el inicio de la actividad e incluso por poder ocasional daños personales, pero es más difícil encajar con las insalubres porque no se trata normalmente de actividades que perjudican la salud humana, ni con las nocivas, en cuanto no encajan bien en un entorno de propiedad horizontal de naturaleza urbana, ni las peligrosas puesto que normalmente el alojamiento turístico nada tiene que ver con las actividades allí descritas.

En cambio, la SAP de Valencia de 10 de junio de 1999, como indica la autora, sostiene que "se puede entender por dañosa, toda aquella actividad que produce o puede producir un daño o perjuicio a la finca; como inmoral, aquella que atenta contra los principios morales vigentes en la sociedad en un momento dado; como peligrosa, la que puede suponer un riesgo potencial o real contra la finca o sus moradores; como incómoda, aquella que determinaría molestias a sus moradores, por falta de comodidad o alteración del ritmo ordinario de la convivencia; y como insalubre, la que atenta contra la salud de los restantes vecinos por sus condiciones malsanas o antihigiénicas. El supuesto que se da con mayor frecuencia es el de actividades incómodas, por la amplitud de su concepto, incluyendo en su seno conductas de todo tipo, tanto referidas a actividades negociables como individuales".

El fundamento de estos supuestos es que estas actividades son contrarias a la normal convivencia de la comunidad, provocando perjuicio o menoscabo al conjunto de la misma, privando o dificultando a los demás del normal y adecuado uso y disfrute de la cosa o derecho, es decir a la normal convivencia de la comunidad.

${ }^{55}$ GoÑ (2018) p. 502. 
Ahora bien, como ya hemos indicado, la mayoría de la doctrina jurisprudencial ${ }^{56}$ indica que no puede declararse en abstracto, sino que es preciso entrar en el análisis de si la concreta actividad llevada a cabo en el inmueble, por su forma de ejercicio, puede ser calificada de conducta contraria a la normal convivencia de la comunidad como indica la sentencia No 37/2016 del Tribunal Superior de Justicia de Cataluña, y teniendo en cuenta la aclaración de la sentencia del mismo Tribunal No 17/2012 en cuanto que "la calificación de una concreta actividad como molesta y contraria a la normal convivencia de la comunidad puede dar lugar por su carácter de concepto jurídico indeterminado a un amplio abanico de posibilidades lo que deviene en una cuestión casuística que deberá ser resuelta conforme a las circunstancias de cada caso concreto". ${ }^{57}$

Por ello, previamente, hay que delimitar lo que entiende la jurisprudencia por "normal convivencia", siendo ésta la que se produce en circunstancias estándares o que se ajusta a las normas o reglas de conducta predeterminadas o fijadas de antemano; pudiendo así, catalogar como las actividades de tipo turístico anómalas, antisociales e incívicas: "el mal uso continuo del ascensor, reiterados ruidos y fiestas nocturnas, los actos de vandalismo, suciedad en los rellanos con restos de comida, botellas y preservativos, y robos, reuniones numerosas y bulliciosas, actividades ruidosas que se desarrollan a altas horas de la noche..$^{58}$

Y una vez identificadas y para que prospere una acción de cesación en estos casos, añade la doctrina jurisprudencial que, con carácter general, esas conductas contrarias a la normal convivencia tienen que ser permanentes, incómodas y notorias

\footnotetext{
${ }^{56}$ Así lo viene señalando en términos generales el TS desde la sentencia $\mathrm{N}^{\circ} 739 / 1993$ y en particular en la SAP de Madrid (sección 9 $9^{a}$ № 383/2010 y en la sentencia del Juzgado de Primera Instancia de Granada No 130/2018.

${ }^{57}$ También existe otra línea interpretativa que considera que la actividad de hostelería que se lleva a cabo en el inmueble objetivamente afecta a la normal convivencia del resto de comuneros en los términos que prohíbe la norma, calificándola como actividad incómoda. Este es el caso de la sentencia de la Audiencia Provincial de Salamanca (sección 1 $1^{\mathrm{a}}$ ) N $\mathrm{N}^{\mathrm{o}}$ 591/2017 7 o la de la Audiencia Provincial de Valencia (sección 11) № 25/2017.

${ }^{58}$ Sentencia del Tribunal de Justicia de Cataluña No 28/2014, con cita de la sentencia No 17/2012 del mismo tribunal y la sentencia de la Audiencia Provincial de Valencia (sección 11ª) No 25/2017.
} 
y ostensible, es decir que se realicen actos de forma frecuente y con asiduidad, que cause molestias o daños concretos a los vecinos de la comunidad de propietario ${ }^{59}$.

\section{Presupuestos Procesales de la Acción de Cesación}

\section{a) El requerimiento previo para el cese de la actividad}

Para poder interponer la acción de cesación es necesario que se realice un requerimiento previo al propietario u ocupante infractor indicándole que cese en la vivienda la actividad. ${ }^{60}$

Por tanto, ante una actividad que cause molestias o daños a la comunidad, cualquier propietario de vivienda del edificio lo podrá poner en conocimiento del Presidente de la Comunidad,- o el propio presidente ante el conocimiento directo de las misma-, el cual tiene que poner en conocimiento del propietario de la vivienda causante de las mismas, que la comunidad no tolerará las concretas actividades e instarle a que cese en el desarrollo de la misma, en un plazo determinado y bajo apercibimiento de iniciar las acciones judiciales ${ }^{61}$.

Esta comunicación se deberá realizar de forma fehaciente ya que el artículo 7.2 LPH utiliza el término "requerimiento", en consecuencia, no puede tratarse

\footnotetext{
${ }^{59}$ No son pocas las Sentencias de Audiencias Provinciales en esa línea: SAP de Salamanca No 252/2000, SAP de Tarragona de 23 de mayo de 2002, SAP de Barcelona No 252/2000, SAP de Valencia (sección $11^{\circ}$ ) № 512/2013, SAP de Valencia 79/2015, SAP de Barcelona № 379/2015, entre otras. En particular la SAP de Salamanca No 252/2000, señala que es necesario que "la molestia sea notoria y ostensible, esto es, no basta una pequeña dificultad o trastorno, sino que se exige un daño de gravedad" y en la sentencia de la Audiencia Provincial de Valencia, (sección 6.") N ${ }^{\circ}$ 391/2008, en la que se insiste en la importancia de la prueba testifical en las actividades molestas, ya que "llega a la convicción el Tribunal que la concreta prueba de las molestias que atentan contra la convivencia comunal".

${ }^{60}$ Según Magro (2011) (www.laleydigital.laleynext.es/ 16048/2011) y (2016a) p. 11, el requerimiento es imprescindible para poder interponer la vía judicial y la inexistencia de éste puede dar lugar a problemas formales que conlleven la desestimación de la demanda.

${ }^{61}$ El requerimiento lo tiene que hacer el representante de la comunidad es decir el presidente o el administrador por mandato del presidente, aunque hay voces que para agilizar el proceso opinan que también tendría que ser posible que los realizara el administrador profesional nombrado. Vid. BARRoso (2013).
} 
de una mera comunicación, sino tiene que hacerse de forma que el documento acredite que el acto de comunicación llegó a su destino y que por tanto tuvo de él conocimiento el destinatario ${ }^{62}$.

En el supuesto de que no se pueda practicar el requerimiento al propietario $\mathrm{u}$ ocupante, se tendrá que realizar, conforme el artículo 9 h) de la LPH, mediante la publicación en el tablón de anuncios de la comunidad o por el medio de comunicación acordado por la comunidad ${ }^{63}$.

En el requerimiento es necesario fijar un plazo prudencial al infractor para que cese voluntariamente en la actividad prohibida. La LPH no fija el plazo por lo que le deja al arbitrio del presidente o de la comunidad para concretarlo. Este plazo será decisivo para la interposición de la acción judicial ya que desde su incumplimiento la comunidad estará legitimada para ejercitarla.

En el caso de que el infractor sea el propio presidente, como señala Luces Gil ${ }^{64}$, habría de proceder a su remoción previa por la junta de propietarios y al nombramiento de un nuevo presidente, conforme a lo establecido en los aptos. 2 y 7 del art. 13 LPH.

Ante la posibilidad de que el presidente de la comunidad se niegue a llevar a efecto el requerimiento, el vecino o los vecinos afectados por las actividades molestas o dañosas, podrán solicitar la convocatoria de una junta y que se proponga como punto del orden del día la realización del requerimiento. Será necesario obtenerse la mayoría del art. 17.3 LPH, y entonces el presidente deberá practicar el requerimiento.

\footnotetext{
${ }^{62}$ Según Magro (2011) (www.laleydigital.laleynext.es/ 16048/2011) tiene que realizarse conforme al art. 149 en relación con el art. 152.2 LEC, con la finalidad de que quede constancia del mismo, así como a la persona a la que debe dirigirse.

${ }^{63}$ (Ibid.) opina que la comunicación también puede entregarse por el conserje de la comunidad, o por el propio administrador de fincas. También es cierto en este punto señalar que es válido utilizar el sistema de comunicación que se haya previsto o concertado con el comunero como puede ser el correo electrónico ${ }^{64}$ LuCES (2000) p. 421.
} 


\section{b) El acuerdo de la Junta para la interposición de la Acción de Cesación}

Practicados los requerimientos de rigor, para dar la oportunidad al infractor de reconsiderar su actitud, en el caso de que no los atienda, se podrá interponer la acción civil de cesación.

Para ello se tendrá que convocar una junta de propietario donde esté incluido en el orden del día autorizar al presidente entablar acción de cesación. Este acuerdo tiene que tomarse conforme al artículo 17.3 LPH, siendo necesario el voto de la mayoría del total de propietarios que a su vez representen la mayoría de las cuotas de participación. Por tanto, será la comunidad de propietario la que tenga la legitimación activa para poder interponer la acción y el presidente actuará como representante de la misma, o lo que es lo mismo el presidente tendrá la legitimación activa para interponer acciones en favor de la comunidad si tiene el acuerdo la misma ${ }^{65}$.

Ahora bien, en los casos en que la Junta de propietario no acuerde la interposición de la acción, la jurisprudencia señala que cualquiera de los copropietarios que soportara directamente estas molestias o las experimentara en mayor grado que el resto, podrá ejercitar en su propio nombre e interés la acción de cesación. Así la STS No321/2016 que indica: " si el presidente o la junta de propietarios, no toma ninguna iniciativa, el propietario individual que sufre en su persona o familia las actividades ilícitas de un copropietario y tras los requerimientos oportunos (como en el caso presente) no puede quedar indefenso y privado de la defensa judicial efectiva, por lo cual tiene la acción de cesación que contempla dicha norma y ante la inactividad del presidente o de la junta (o de ambos) está legitimado para ejercer esta acción en interés propio (no en el de la comunidad) y en defensa de su derecho, que no ha ejercido la comunidad".

\footnotetext{
${ }^{65}$ Sobre la legitimación activa del presidente de la comunidad de propietarios para el ejercicio de acciones procesales ver las sentencias del Tribunal supremo No 732/2011, No 204/2012 y No $659 / 2013$.
}

\section{DERECHO GLOBAL. ESTUDIOS SOBRE DERECHO Y JUSTICIA}


Pero incluso, cualquier propietario puede interponerla en beneficio de la comunidad como ha señalado Tribunal Supremo, tal es el caso de la sentencia $\mathrm{N}^{\mathrm{o}}$ 1013/2004 donde recuerda que cualquiera de los condueños está legitimado procesalmente para ejercitar acciones en beneficio de todos los comuneros ${ }^{66}$.

En lo que respecta a la legitimación pasiva, el párrafo cuarto del apartado segundo del artículo 7.2 establece que "La demanda habrá de dirigirse contra el propietario $y$, en su caso, contra el ocupante de la vivienda o local".

Siguiendo la propia literalidad de la norma, es necesario demandar al propietario $\mathrm{y}$ al ocupante en el caso de que el autor de las actividades prohibidas lo sea el ocupante y no propietario. Es decir, en estos casos estamos ante un litisconsorcio pasivo necesario legal para evitar la posible indefensión del propietario. En cambio, en el caso que nos ocupa, será difícil poder demandar al ocupante, salvo que nos encontramos ante un contrato de arrendamiento de uso turístico de largo plazo (3 meses), pero lo normal es que la cesión de uso de estas viviendas sea de períodos diarios o semanales. Por tanto, aunque en las viviendas de uso turístico sería posible saber quien ocupaba la vivienda en un día particular ya que estarían registradas en la plataforma en la que se oferta la vivienda, creemos que en los caso de viviendas de uso turísticos por períodos breves no sería necesario que la demanda tenga que ir dirigida también al ocupante ${ }^{67}$, y ello por la finalidad de la acción de cesación, es decir que no se use la vivienda concreta con fines turísticos, ya que este uso atentan contra la convivencia comunal.

\footnotetext{
${ }^{66}$ Criterio sentado desde las Sentencias de 9 de febrero y 28 de octubre de 1991 y 15 de julio de 1992 como indica la sentencia. Por ello MaGro (2011) (www.laleydigital.laleynext.es/ 16048/2011), reconoce que el propietario perjudicado puede ejercer las acciones que el Código Civil establece para la relación de vecindad de los artículos 590 y ss., las acciones de responsabilidad civil de los artículos 1902 y 1908, y la acción de cesación del artículo 7.2 LPH.

${ }^{67}$ En este mismo sentido vid. GoÑI (2018) p. 506.
} 
Cuestión diferente es que el propietario que tenga que sufragar los daños o desperfectos ocasionados en la parte común del edificio por el ocupante, pueda repetir contra él o que éstos los cubra el seguro suscrito entre ellos.

\section{c) Las medidas cautelares y pronunciamiento de la sentencia}

Admitida la demanda, el juez puede, si se solicita en la misma, adoptar medidas cautelares para que se anticipe la cesación de la actividad que produce las molestias en la comunidad. Para ello no solo tienen que darse los elementos sustantivos necesarios para interponer la acción, sino también que exista una urgencia o necesidad de que el retraso pueda dar lugar a perjuicios en la comunidad.

Sustanciado el procedimiento y practicada la prueba sobre la existencia de actividad molesta corresponderá al juez resolver sobre la admisibilidad de la pretensión de la comunidad de propietarios.

Si la admite la pretensión, por reconocer que ha existido actividades molestas, el artículo 7.5 LPH nos señala cúal puede ser el contenido de la sentencia. Deberá ordenar la cesación definitiva de la actividad que ha sido objeto de la demanda planteada y la indemnización de los daños y perjuicios que correspondan y además podrá : a) ordenar la privación del derecho al uso turístico de la vivienda o local por tiempo no superior a tres años en función de la gravedad de la infracción y de los perjuicios ocasionados a la comunidad y b) en el caso de que el infractor no fuera el propietario y arrendamiento de uso turístico se mantuviera con el mismo ocupante, se podrá declarar extinguido el mismo y su inmediato lanzamiento ${ }^{68}$, posibilidad esta última poco probable.

Por último, esta acción tiene un plazo de prescripción de 15 años, por los que como indica Gil Noguera, ${ }^{69}$ difícilmente podrá prescribir. Ahora bien, si la actividad de

${ }^{68} \mathrm{Vid}$. MAGRO (2011) (www.laleydigital.laleynext.es/ 16048/2011).

${ }^{69}$ GIL (2005) p. 10. 
uso turístico lleva mucho tiempo realizándose y causando menoscabo y daño a la comunidad "la acción puede ejercitarse mientras se esté produciendo la actividad que se reputa prohibida por el régimen de propiedad horizontal, de modo semejante a como se pronuncia la Jurisprudencia respecto de los daños continuados en los que no comienza a correr el plazo de prescripción mientras no desaparezca la causa determinante del daño" como señaló la sentencia de la Audiencia Provincial de Madrid de 7 de septiembre de 1993 (AC 1993\1969).

\section{Conclusiones}

El uso o la cesión de una vivienda de uso turístico o vacacional se regulaba en virtud de un contrato de arrendamiento que, hasta el año 2013, era un arrendamiento de temporada regulado por la LAU. Desde este momento se ha excluido de su regulación, cuando ha sido "comercializada o promocionada en canales de oferta turística y [...] cuando esté sometida a un régimen específico, derivado de su normativa sectorial" (art. 5.e) y desde Real Decreto-ley 7/2019, que ha ampliado las vías de comercialización o promoción a "cualquier otro modo de comercialización o promoción”.

Actualmente, por tanto, habrá contrato de vivienda de uso turístico cuando la oferta y la contratación de la vivienda se haya hecho a través de canales de oferta turística (redes p2p, páginas web, agencias de viaje, empresas mediadoras) o por cualquier otro modo de comercialización o promoción (prensa tradicional) y cuando en la Comunidad Autónoma en la que radique exista una norma que lo regule; y habrá contrato de arrendamiento de temporada, regulado por la LAU, cuando en la Comunidad Autónoma no se haya regulado específicamente la cesión de vivienda vacacional o cuando al contrato no haya precedido comercialización o promoción, y la oferta se haya hecho privadamente.

La cuestión de la norma sectorial no plantea cuestión, se tiene o no, pero sii lo referente a la actividad, aunque el artículo 5.e) de la LAU no lo digan, la verdadera línea de 
separación entre el arrendamiento de temporada y la cesión de vivienda de uso turístico no está en la forma en que se haga la oferta contractual, sino en la actividad. El legislador quiere evitar el "intrusismo y [la] competencia desleal” (Preámbulo II, in fine), quiere evitar el ejercicio de la actividad turística desde fuera del sector turístico, por ello establece que contratar a través de canales de oferta turística o por cualquier otro modo de comercialización o promoción es solo la evidencia de que existe una actividad turística, siendo ella la que produce la exclusión de la LAU.

Cuando esta actividad se realiza en vivienda situada en un edificio en régimen de propiedad horizontal ante las reales o previsibles molestias que las existencias de viviendas turísticas pudieran generar para el conjunto de los residentes, se ha planteado la prohibición o limitación de esta actividad. Sin embargo, el uso turístico de vivienda sita en un edificio en régimen de propiedad horizontal no está prohibido por ninguna norma de carácter general, lo único que está prohibido es la actividad molesta, cuando la actividad de cesión de vivienda de uso turístico lo sea, de conformidad con el Decreto 2414/1961, de 30 de noviembre, por el que se aprueba el Reglamento de Actividades Molestas, Insalubres, Nocivas y Peligrosas. Pero lo que sí ha hecho una norma general -el Real Decreto-ley 7/2019, de 1 de marzo, de Medidas urgentes en materia de vivienda y alquiler, que ha introducido en el artículo 17 de la Ley de Propiedad Horizontal (LPH) un apartado 12- es facilitar a las comunidades de propietarios que puedan, mediante acuerdos de la Junta, regular o prohibir los alquileres vacacionales en el edificio.

En principio el fundamento de esta limitación por la comunidad de propietario, según la doctrina jurisprudencial, está en el carácter perjudicial para la finca el ejercicio de la actividad turística y se puede producir por diferentes vías: originaria, por la prohibición expresa en el título de constitutivo o en los estatutos (inscritos, en su caso, en el Registro de la Propiedad), o derivada, por el acuerdo de la junta de propietarios.

Esta vía derivada, de acordar por la junta de propietario que se limite los usos que pueden ser desarrollados en los elementos privativos, excluyendo el de vivienda 
de uso turístico, hasta finales de 2018 ha sido muy difícil por el requisito de la unanimidad que exigía de LPH. Con el fin de facilitar estos acuerdos se modificó la LPH por el Real Decreto-ley 7/2019, de 1 de marzo, de medidas urgentes en materia de vivienda y alquiler, incluyendo un apartado 12 en su artículo 17, donde se establece la posibilidad de limitar o condicionar la actividad que se refiere la letra e) del artículo 5 de la LAU (vivienda de uso turístico) suponga o no modificación del título constitutivo o de los estatutos, requiriendo el voto favorable de las tres quintas partes del total de los propietarios que, a su vez, representen las tres quintas partes de las cuotas de participación.

También pueden, limitarse la actividad turística en edificio en régimen de propiedad horizontal mediante el art. 7.2 de la LPH, que regula la acción de cesación o prohibición de una actividad por parte de la comunidad de vecinos cuando estén "prohibidas en los estatutos, que resulten dañosas para la finca o que contravenga disposiciones generales sobre actividades insalubres, nocivas, peligrosas o ilícitas".

Ahora bien, no podemos afirmar, per se, que el uso de una vivienda para destino turístico contravenga las disposiciones generales sobre actividades que resulten molestas, insalubres, nocivas, peligrosas, ilícitas, lo que es lo mismo que sean contrarias a la convivencia normal de la comunidad o la integridad del edificio, y mucho menos cuando se encuentran reguladas por la legislación sectorial. Sin embargo, está siendo muy frecuente que, en determinadas zonas y ciudades, especialmente en temporada vacacional, los usuarios de estas viviendas lleven a cabo actividades ruidosas, se congreguen en un mismo apartamento para realizar actividades de ocio (beber, bailar, etc.), y otras conductas incívicas y antisociales, dando lugar a que los propietarios del inmueble, se le generen grandes molestias personales y materiales. Pues bien, en estos casos procederá la acción de cesación. 


\section{Bibliografía}

Arnaiz Ramos, R. (2017): "Las viviendas de uso turístico y el Registro de la Propiedad", Boletín. Servicio de Estudios Registrales de Catalunya, núm. 185 pp. 162-167.

Barroso González, J.M. (2013): "Requisitos de procedibilidad para el planteamiento de acciones de cesación de actividades prohibidas", La Ley digital (Disponible en http://www.laleydigital.laleynext.es/ 8449/2013).

Bethencourt Rodríguez, G (2019): "La comunidad de propietarios ante el fenómeno del alquiler vacacional” RCDI, núm. 776, pp. 3040-3060. Cabezuelo Arenas, al. (2018): "Edificios sometidos a propiedad horizontal y arriendo turístico de pisos: tres vías de prevención y/o defensa de la Comunidad frente a una actividad potencialmente molesta", Revista Aranzadi Doctrinal, núm. 5, pp. 19-51

Carrasco Perera, a. (2019):" Acuerdos comunitarios contra los alquileres turísticos". Actualidad Jurídica Aranzadi, núm. 948 (Disponible en http://www.aranzadidigital.es/BIB 2019\595)

Cerdeira bravo de mansilla, G. (2018): "Pisos turísticos y comunidades de vecinos: un posible caso de abuso de derecho", Revista de Derecho Privado, enero-febrero, pp. 53-88.

Cremades Morant, J. (2012): "Usos turísticos y propiedad horizontal".

Sepin, (Disponible en http://www.sepin.es/2012SP/DOCT/16915)

Estrada Alonso, E. (1997): "El desfase de la Ley de Propiedad Horizontal en los grandes conjuntos inmobiliarios”, A.C., núm. 31, pp. 694-723. Echeverría Summers, F.M. (1997): "STS 20 de febrero 1997. Actividades prohibidas en los Estatutos. Resolución del contrato de arrendamiento de local de negocio. Costas procesales", CCJC, núm. 44 pp. 691-710. Fuentes-Lojo Rius, A., (2018): "Las normas comunitarias que regulen la actividad turística que se desarrolle en elementos privativos del inmueble ¿son normas de naturaleza estatutaria o son normas 
relativas al reglamento de régimen interior de la comunidad?", Actualidad Civil, núm. 7-8 (Disponible en http://www laleydigital. laleynext.es/7839/2018)

Gil Nogueras, L.A. (2005): "Notas sobre la interpretación por los tribunales del art. 7.2 LPH”, Práctica de Tribunales, núm. 17, pp. 6-20.

Guillén Navarro, N.A. (2015): "La vivienda de uso turístico y su incidencia en el panorama normativo español", Revista Aragonesa de Administración, núm. 45-46, pp. 101-144.

González Carrasco, M.C. (2015): "Propiedad horizontal: el propietario puede convertir su local en vivienda si reúne las condiciones de habitabilidad (Comentario a la STS de 3 de diciembre de 2014)", CESCO, (Disponible en www.uclm.es/centro/cesco).

González Papanowsca, I., (2003): "STS 13 de marzo 2003. Propiedad horizontal. Impugnación del acuerdo de Comunidad de Propietarios de destinar los pisos a uso distinto del de vivienda. Falta de unanimidad. Impugnación judicial”, CCJC, núm. 62 pp. 857-873.

Goñi Rodríguez de Almeida, M. (2018): "El alquiler vacacional como actividad molesta en la comunidad de propietarios", $R C D I$, 94, núm. 765 pp. 496-512.

Guillén Navarro, N.A. (2015), "La vivienda de uso turístico y su incidencia en el panorama normativo español", Revista Aragonesa de Administración, núm. 45-46, pp. 101-144.

Loscertales Fuertes, D. (2016): "Actividades molestas ¿Puede la comunidad de propietarios impedir que una vivienda se destine al uso turístico? TSJ Catalunya, Sala civil y Penal, Sec. 1. a , 19-5-2016 SP/SENT/855707, TSJ Cataluña, Sala de lo Civil y Penal, sec. 1. , 19-5-2016 SP/SENT/855708", en Jurisprudencia comentada. Sepin, (Disponible en http://www.sepin.es/2016SP/DOCT/20408) Luces Gil, (2000): "Los nuevos procesos de la Ley de Propiedad Horizontal (La Ley 46/1960)", Actualidad Civil, núm. 1, pp. 421-448. 
Magro Servet, v. (2011). "Aspectos procesales y sustantivos de las acciones de cesación del artículo 7. 2 de la Ley de Propiedad Horizontal en las comunidades de propietarios", La Ley Digital (Disponible en http://www.laleydigital.laleynext.es/ 16048/2011).

Magro Servet, V. (2016): "Adopción de acuerdos sobre prohibición de dedicación de locales a negocios de hostelería. ¿Son válidos? ¿Exceso de prohibición?", Revista de Derecho Inmobiliario. (Disponible en http://www.elderecho.com/tribuna/civil/11_10185 55001.html.)

Magro Servet, V. (2016a) "La acción de cesación en el régimen de la Propiedad Horizontal", Práctica de Tribunales: Revista de Derecho procesal civil y mercantil, núm. 120 (mayo-junio. 1-7), p. 11

Martí Martí, J. (2016) "El acuerdo comunitario de limitación de uso de las entidades de la finca como pisos turísticos", Sepin (Disponible en http://www sepin.es/ SP/DOCT/20166)

Merino Espinar, B. (2016) "Ley de Propiedad Horizontal. Los límites al uso de los elementos privativos deben ser expresos y deben constar inscritos en el Registro de la Propiedad para afectar a terceros. Los requisitos impuestos por la normativa urbanística. Comentario de la sentencia del Tribunal Supremo de 12 de septiembre de 2013 (5067/2013)", en Yzquierdo Tolsada, M. (coord.), Comentarios a las sentencias de unificación de doctrina: civil y mercantil (20132014), vol. 6 (Madrid, Editorial Dykinson), pp. 537-554.

Mesa Marrero, C. (2019): "Las viviendas de uso turístico y la cuestión competencial en materia civil", Indret: Revista para el Análisis del Derecho, No. 3 (Disponible en http://www.indret.com/pdf/1483.pdf) Sánchez González, M.P.(2016): Régimen de adopción de acuerdos en materia de propiedad horizontal: distintas mayorias y procedimientos para su consecución, (Cizur Menor, Editorial Thomson Reuters Aranzadi,).

San Cristóbal reales, S. (2009:) "El juicio para la cesación de actividades prohibidas en el ámbito de la propiedad horizontal", Anuario Jurídico Escurialenses, XLII, pp. 61-84. 
Vila Marín, F. (2016): "El uso de pisos turísticos no se considera una actividad contraria a la convivencia normal", Inmueble: Revista del sector inmobiliario, núm. 164, pp. 38-41.

Normas citadas

Ley No49 (02/07/1960), sobre Propiedad Horizontal.

Decreto $N^{\circ} 2414$ (30/11/1961) de Reglamento de Actividades Molestas, Insalubres, Nocivas y Peligrosas.

Ley $\mathrm{N}^{0} 29(24 / 11 / 1994)$ de Arrendamientos Urbanos

Ley $\mathrm{N}^{\mathrm{o}} 4(04 / 06 / 2013)$ de medidas de flexibilización y fomento del mercado de alquiler de viviendas.

Real Decreto-Ley No21 (13/12/2018) y Real Decreto-Ley No7 (01/03/2019) de Medidas urgentes en materia de vivienda y alquiler.

\section{Código Civil De Cataluña}

Ley No 8 (19/07/2012) del Turismo de las Illes Balears

Decreto $\mathrm{N}^{\mathrm{0}} 28(02 / 02 / 2016)$ de las viviendas con fines turísticos de la Comunidad Andaluza.

Decreto $N^{o} 48$ (10/08/2016) de viviendas vacacionales y viviendas de uso turístico del Principado de Asturias

Decreto $N^{0} 12$ (16/01/2017) de ordenación de apartamentos turísticos y viviendas turísticas de Galicia

LEY No15 (07/06/2018) de turismo, ocio y hospitalidad de la Comunidad Valenciana

\section{RELACIÓN DE SENTENCIAS}

España: STS No 739/1993de 16 de julio (RJ 1993\6155)

España: STS No 134/1997de 20 de febrero (RJ 1997/1244).

España: STS No 1013/2004 de 14 de octubre (RJ 2004\6569)

España: STS No 997/2005 de 14 de diciembre (RJ 2005\10167)

España: STS No 123/2006 de 23 de febrero (RJ 2006\910). 
España: STS N ${ }^{\circ} 1023 / 2007$ de 10 de octubre (RJ 2007\8420)

España: STS No 7/2008 de 16 de mayo (RJ 2008\3081)

España: STS No 452/2008 de 22 de mayo (RJ 2008\3166)

España: STS No 1152/2008 de 27 noviembre (RJ 2008\6069)

España: STS No 335/2009 de 29 de mayo (RJ 2009\4222)

España: STS No 732/2011 de 10 de octubre (RJ 2011 \7410)

España: STS No 894/2011 de 30 de noviembre (RJ 2012 \3515)

España: STS No 86/2012 de 20 de febrero (RJ 2012\4043)

España: STS No 204/2012 de 27 de marzo (RJ 2012\4061)

España: STS No 183/2013 de 7 marzo (RJ 2013\3480)

España: STS No 659/2013 de 19 de febrero (RJ 2014, 1135)

España: STS N ${ }^{o} 321 / 2016$ de 18 de mayo (RJ 2016\3676)

España: STS No 678/2016 de 17 de noviembre (RJ 2016\5608)

España: STS No 358/2018 de 15 de junio (RJ 2018/2453)

España: STS No 442/2018 de 12 de Julio (R2018\2823)

España: STSJ de Cataluña No 17/2012 de 20 de febrero (RJ 2012\10019)

España: STSJ de Cataluña No 28/2014 de 28 de abril (RJ 2014\3563)

España: STSJ de Cataluña No 37/2016 de 19 de mayo (RJ 2016\3653)

España: SAP de Madrid de 7 septiembre de 1993. (AC 1993\1969)

España: SAP de Salamanca No 252/2000 de 4 de mayo (AC 2000\2306)

España: SAP de Tarragona de 23 de mayo de 2002 (JUR 2002\208417)

España: SAP de Valencia (sección 6. ${ }^{\text {a) }} \mathrm{N}^{\mathrm{o}}$ 391/2008de 10 de junio (JUR 2009\380221)

España: SAP de Barcelona (sección 17. a) No 505/2008 de 20 octubre. (JUR 2009\146710)

España: SAP de las Islas Baleares (sección 5a) No 419/2009 de 10 diciembre. (AC 2010\81)

España: SAP de Madrid (sección 9 ${ }^{a}$ ) No 383/2010 de 19 de julio (AC 2010\1288)

España: SAP de Barcelona No 238/2011de 6 de mayo (JUR 2011 294432) España: SAP de Barcelona No 384/2011de 12 de julio (JUR 2011\318655) 
España: SAP de Valencia (sección $11^{\circ}$ ) N $\mathrm{N}^{\mathrm{o}} 512 / 2013$ e 20 noviembre. (JUR 2014\185706)

España: SAP de Valencia No 79/2015 de 25 de marzo (JUR 2015\145287) España: SAP de Barcelona No 379/2015 de 9 de octubre (AC 2016 24) España: SAP de Barcelona (sección 1 ${ }^{\mathrm{a}}$ ) $\mathrm{N}^{\mathrm{o}}$ 34/2017 de 3 de febrero (JUR 2017\224786)

España: SAP Valencia (sección 11ª) No 25/2017de de 6 de febrero (JUR 2017\130291)

España: SAP de Barcelona (sección 13 ${ }^{\mathrm{a}}$ ) No392/2017 de 5 julio (JUR 2017\265876)

España: SAP de Salamanca (sección 1ª) No 591/2017 del 29 de diciembre (AC 2017 \1968)

España: SAP de Barcelona (sección 1ª) No 708/2017de 27 de diciembre (AC 2017 \1701)

España: S. del Juzgado de Primera Instancia de Granada, núm. 130/2018, de 18 septiembre, (JUR\2018\256463) 
